\title{
Z ZAGADNIEŃ PRAWNOORGANIZACYJNYCH WŁADZ SAMORZACDU TERYTORIALNEGO (KILKA UWAG I REFLEKSJI W KWESTIACH WYBRANYCH)
}

I. Przypadająca w tym roku 30. rocznica reaktywowania w systemie polityczno-ustrojowym i prawnoadministracyjnym Rzeczypospolitej Polskiej instytucji samorządu terytorialnego zaznacza bardzo istotny przełom w kształtowaniu struktury władzy publicznej na gruncie założeń demokratycznego państwa prawnego. Byłoby jednak uproszczeniem odniesienie tej rocznicy jedynie do momentu prawnego zainstalowania samorządu terytorialnego w obowiązującym porządku prawnym, co nastapiło za sprawą ustawy z 8 marca 1990 r. o samorządzie gminnym ${ }^{1}$. Na tę rocznicę patrzeć można (i należy) szerzej, z perspektywy całego trzydziestoletniego okresu istnienia samorządu ${ }^{2}$, w którym podlegał on systematycznemu rozwojowi i wzmacnianiu jako jeden z podstawowych filarów administracji publicznej. Ten proces rozwojowy nie przebiegał gładko i bezproblemowo, w jego trakcie pojawiały się (i ścierały) różne pomysły, idee i stanowiska w kwestiach zasadniczych, dotyczących roli, znaczenia i miejsca samorządu terytorialnego w systemie władzy publicznej ${ }^{3}$. Towarzyszyły temu również szerokie dyskusje w bardziej szczegółowych kwestiach, związanych z prawnym ukształtowaniem organizacji i zasad działania samorządu terytorialnego (jak chociażby kwestia wprowadzenia organu wykonawczego w samorządzie gminnym w postaci organu monokratycznego, obsadzanego personalnie w drodze wyborów powszechnych). Pomimo całej złożoności kształtowania się samorządu i meandrów, jakie występowały na drodze tego kształtowania, przez minione trzydzieści lat konsekwentnie ugruntowywał on swoja rolę i pozycję jako prawna instytucja terytorialnego ustroju Rzeczypospolitej Polskiej.

W rezultacie nie ma żadnej wątpliwości, że samorząd jest dziśs trwale ulokowanym (konstytucyjnie zapisanym - art. 16, a także rozdz. VII Konstytucji) składnikiem systemu sprawowania władzy publicznej w RP i bardzo istotnym

${ }^{1}$ Dz. U. Nr 16, poz. 95, t.jedn.: Dz. U. 2019, poz. 506 (dalej jako: u.s.g.).

${ }^{2}$ Trafnie przy okazji jubileuszu 25-lecia samorządu terytorialnego podkreślał ten szerszy aspekt „rocznicowy” Jan Zimmermann (2015: 131), pisząc, że nie chodzi o upamiętnienie jednostkowego zdarzenia sprzed lat, ale o „rocznicę, która pozwala na wypełnienie realną, ważna i pozytywną treścią całego okresu".

${ }^{3}$ Jak np. w przypadku realizacji koncepcji umiejscowienia samorządu na trzech poziomach zarządzania, tj. gminnym, powiatowym i wojewódzkim, w tym postrzegania pozycji samorządu wojewódzkiego (czym ma być?) w konfrontacji z wizją administracji rządowej w województwie. 
ogniwem szerokiego mechanizmu zawiadywania sprawami społeczeństwa i państwa. Co więcej, trudno sobie realnie wyobrazić, że w tym systemie organizacyjnym i mechanizmie funkcjonowania władzy publicznej w terenie nie ma samorządu terytorialnego ${ }^{4}$. Jest to wszakże jedna $\mathrm{z}$ fundamentalnych instytucji demokratycznego państwa prawnego ${ }^{5}$.

Wszystko to oczywiście nie oznacza, że samorząd terytorialny w RP osiagną optymalny poziom rozwoju i prezentuje się jako instytucja ustrojowa ukształtowana ostatecznie, niebudząca żadnych istotniejszych problemów i wolna od potrzeby systematycznego monitorowania jej funkcjonowania w praktyce i ewentualnego podejmowania na tym tle dyskusji i działań służących ulepszaniu istniejaccego modelu. Problematyka samorządu terytorialnego pozostaje zatem cały czas materią „żywą, podatną na dyskusję, wymianę poglądów i propozycje nowych rozwiązań w sferze organizacyjnej, funkcjonalnej, kadrowej itd., która wychodząc z generalnych idei dotyczacych roli i wartości samorządu terytorialnego w demokratycznym państwie prawnym (i podkreślając jego niezbędność w coraz szerszym zakresie w sprawowaniu władzy publicznej), służyć mają modernizacji i doskonaleniu jego organizacji i funkcjonowania.

Przypadajaca w tym roku okragła 30. rocznica włączenia na powrót samorządu terytorialnego w system sprawowania władzy publicznej w Polsce daje - tak jak zreszta każdy jubileusz - dobra okazję do refleksji w odniesieniu do różnych aspektów tej bardzo bogatej problematyki samorządowej. Korzystając z tej okazji, chciałbym przedstawić parę uwag i spostrzeżeń na temat niektórych zagadnień prawnoorganizacyjnej regulacji w zakresie władz samorządu terytorialnego.

II. Przegląd tych zagadnień zacząć można od zwrócenia uwagi na treść samej wspomnianej kategorii „władze samorządu terytorialnego” (,władze samorządowe”)

Pojęcie „władza” nie ma jednoznacznej, utrwalonej treści i może stać za nim różny sens znaczeniowy w zależności od tego, w jakiej przestrzeni (kontekście) pojęcie to występuje i jest rozpatrywane ${ }^{6}$. Na płaszczyźnie prawnej, zarówno

${ }^{4}$ Chodzi tu nie tylko o konieczność dochowywania dyrektyw płynących z Konstytucji, że ustrój terenowy RP opiera się na decentralizacji (art. 15 ust. 1) i że jego naturalnym i koniecznym komponentem jest samorząd terytorialny (art. 16 ust. 2), ale także o to, że instytucja samorządu terytorialnego jest zakodowana w odbiorze społecznym jako oczywisty, naturalny wyraz codziennego funkcjonowania władzy publicznej w terenie, odpowiedzialnej zarówno za rozwiązywanie problemów całej społeczności lokalnej, jak i załatwianie spraw indywidualnych członków tej społeczności.

${ }^{5} \mathrm{~W}$ uproszczonym hasłowym stwierdzeniu na temat ustrojowej roli i znaczenia samorządu można powiedzieć, że nie ma ustroju terytorialnego RP innego niż oparty na decentralizacji i nie ma decentralizacji bez samorządu terytorialnego.

${ }^{6}$ Wystarczy odczytać hasło „władza” w słownikach języka polskiego, aby przekonać się o zróżnicowanym rozumieniu tego pojęcia, towarzyszącym jego używaniu. Na przykład władza $\mathrm{w}$ kontekście politycznym, prawnym, ustrojowym to z jednej strony rządzenie, kierowanie państwem, panowanie, z drugiej - organy rządzące, instytucje kierujące czymś. Na tym tle pojawiają się rozliczne rodzaje władzy (czy władz), jak np. władze administracyjne, władza ustawodawcza, władze lokalowe, władza publiczna, władze partyjne, władza centralna itd. Ale już czym innym 
normatywnej, jak i teoretycznej, naukowej (w języku prawnym i prawniczym) pojęcie władzy pojawia się zasadniczo w dwojakim znaczeniu: funkcjonalnym oraz podmiotowym (organizacyjnym). W pierwszym z nich „władza” wyraża pewną funkcję, charakterystyczny rodzaj zachowania (działania), którego istota sprowadza się do możliwości oddziaływania w sposób jednostronny i wiążący przez dysponującego władzą na inne podmioty, ich zachowania, pozycję i sytuację itd., jak również do możności stanowczego wpływania na funkcjonowanie szerszych zbiorowości przez kształtowanie obowiązujących reguł, norm postępowania itp. ${ }^{7} \mathrm{Z}$ kolei we wspomnianym podmiotowym sensie pojęcie władzy (czy władz) odnoszone jest do szeroko postrzeganej kategorii podmiotów sprawujących władzę, jak organy, instytucje, urzędy i inne jednostki organizacyjne, posiadajace możliwość podejmowania działań władczych.

Przechodząc do interesujacej nas problematyki władz samorządowych, należy zauważyć, iż pojęciem władz w odniesieniu do poszczególnych jednostek samorządu posługują się - i to w obu wspomnianych znaczeniach - wszystkie tzw. ustrojowe ustawy samorządowe ${ }^{8}$. Każda z nich zawiera w swej konstrukcji formalnej rozdział 3 zatytułowany: „Władze gminy”, „Władze powiatu”, „Władze województwa”, obejmujacy w dość szerokim zakresie regulację prawną sfery organizacyjnej danej jednostki samorządu terytorialnego. W samym tytule kategoria „władz” jawi się w sposób bardzo pojemny, skoro występujące pod tym hasłem unormowania wskazują nie tylko podmioty wykonujace władzę w określonej jednostce samorządu (jak mieszkańcy wspólnoty oraz jej organy), lecz odnoszą się także do szczegółowych rozwiązań organizacyjnych w obrębie tych podmiotów (władz) i towarzyszących im jednostek organizacyjnych, których kwalifikacja en bloc do rzędu władz gminy, powiatu czy województwa jest bardzo wątpliwa ${ }^{9}$. Można odnieść wrażenie, że kategoria władz samorządowych ujmowana jest tu w dość swobodnej konwencji rozumienia pojęcia władzy, odwołującej się do jej pojmowania w języku codziennym, potocznym.

Równocześnie jednak w regulacjach ustawowych, o których tu mowa, wyczytać można kategorię władz samorządowych w ściślejszym, jurydycznym sensie. W pierwszym rzędzie jako władze poszczególnych jednostek samo-

jawi się np. władza rodzicielska (prawnie określona) czy władza rozumiana jako zdolność panowania nad czynnościami własnego organizmu (np. władza w nogach), czy zdolność myślenia, rozumowania, odczuwania (tzw. władze umysłowe). Por. np. Dubisz (2006): s.v.

${ }^{7}$ Pojęciu władzy z tej funkcjonalnej perspektywy towarzyszy często sięganie do takich określeń, jak m.in. panowanie, rządzenie, kierowanie, decydowanie, czy innych jeszcze wyrażeń odzwierciedlających możność oddziaływania wiążącego, wymagającego respektowania zawartych w nim treści.

8 Tzn. przywoływana już ustawa z 8 marca 1990 r., t.jedn.: Dz. U. 2019, poz. 506, a także ustawa z 5 czerwca 1998 r. o samorządzie powiatowym, t.jedn.: Dz. U. 2019, poz. 511 (dalej jako: u.s.p.) oraz ustawa z 5 czerwca 1998 r. o samorządzie województwa, t.jedn.: Dz. U. 2019, poz. 512 (dalej jako: u.s.w.).

${ }_{9} \mathrm{O}$ ile można jeszcze w kategoriach władzy rozpatrywać np. stanowisko starosty czy marszałka województwa, nawet stanowiska przewodniczących organów stanowiących i kontrolnych samorządu, bądź też organy wewnętrzne tych organów z tej racji, że stanowią elementy struktury organizacyjnej podmiotów, mających niewątpliwie walor władzy, o tyle kontrowersje budzić musi uznawanie za władze urzędów administracyjnych (np. urząd gminy czy urząd marszałkowski) czy np. jednostek pomocniczych gminy i ich organów. 
rządu terytorialnego wskazani są mieszkańcy gmin, powiatów i województw. W każdej z ustaw znajdujemy niemalże identycznie brzmiące normy (art. 11 ust. 1 u.s.g., art. 8 ust. 1 u.s.p., art. 5 ust. 1 u.s.w.) stanowiące o tym, że mieszkańcy, odpowiednio, gminy, powiatu i województwa podejmuja rozstrzygnięcia w głosowaniu powszechnym - przez wybory i referendum lub za pośrednictwem organów gminy, powiatu i samorządu województwa. I choć stylistyka ujęcia tej normy (norm) może wzbudzać pewne zastrzeżenia, to merytoryczna treść tego unormowania zawiera dość jasne ustalenie, że podstawowym (jeśli nie jedynym) podmiotem władzy, zarówno z punktu widzenia jej posiadania, jak i wykonywania, jest w poszczególnych jednostkach samorządu wspólnota samorządowa, ogół mieszkańców gminy, powiatu czy województwa. Wspólnota mieszkańców jako podmiot władzy działać może bezpośrednio, poprzez instytucję wyborów oraz referendum, bądź pośrednio - poprzez swoje organy. W konsekwencji przymiot władz samorządowych należy przypisać (obok poszczególnym wspólnotom) także organom gmin, powiatów i województw. W ten oto sposób obowiązujący porządek prawny kształtuje kategorię władz jednostek samorządu terytorialnego, zaliczając do niej ogół mieszkańców gminy, powiatu i województwa oraz ustanowione przez stosowne przepisy organy tych jednostek samorządu.

W związku z tym można jednak zapytać, czy tej bardzo ważnej kwestii nie należałoby ujaćc w lepszej formule legislacyjnej. W obecnym ujęciu sprawa władzy w samorządzie terytorialnym i władz samorządowych (w sensie organizacyjnym) prezentowana jest poprzez zaakcentowanie form, w jakich wypowiadają się stanowczo, władczo (tu: rozstrzyganie) mieszkańcy gminy, powiatu czy województwa. To wskazanie sposobów podejmowania rozstrzygnięć przez mieszkańców powinno być wszakże poprzedzone jednoznacznym określeniem wprost, kto jest podmiotem posiadającym i wykonujaccym władzę publiczna w gminie i innym ogniwie samorządu terytorialnego. Określenie (choć dziś wywodzone w drodze interpretacji), że tym podstawowym podmiotem władzy jest wspólnota samorządowa (mieszkańcy) jest o tyle istotne, że nawiązuje do źródeł ideowych samorządu, polegających m.in. na konieczności - wynikającej z wielorakich przesłanek - podzielenia się przez państwo władzą (administracja) publiczną z wyodrębnionymi prawem podmiotami, w naszym przypadku typu korporacyjnego, tj. wspólnotami mieszkańców, które w efekcie zostaja wyposażone w część owej władzy (administracji) na trwałe, do wykonywania jej we własnym imieniu i na własną odpowiedzialność, pod określonym prawnie nadzorem państwa. Taka jednoznaczna normatywnie deklaracja co do władz samorządowych dobrze służyłaby podkreśleniu roli i znaczenia samorządu terytorialnego w systemie polityczno-ustrojowym państwa.

III. W ramach problematyki władz samorządowych uwagę zwraca zagadnienie organów jednostek samorządu (gmin, powiatów, województw) zaliczanych zasadnie do kategorii władz, o czym było wzmiankowane we wcześniejszych uwagach. W tym miejscu warto nieco bliżej spojrzeć na to zagadnienie, które na pozór bezproblemowe i niebudzące jakichś zasadniczych kontrowersji, skłania jednak do pewnych refleksji. W pierwszej kolejności można je odnieść 
do przyjętego modelu organów poszczególnych jednostek samorządu. Generalnie w świetle ustaw ustrojowych jest on przejrzysty i nawiązując do tradycyjnych w tej mierze rozwiązań, obejmuje dwie kategorie organów, tj. organy stanowiące i kontrolne oraz organy wykonawcze. Wszystkie one wymienione sa wprost $\mathrm{w}$ regulacjach ustawowych w postaci rady gminy, powiatu oraz sejmiku województwa - organy stanowiące i kontrolne, oraz wójta (burmistrza, prezydenta), zarządu powiatu i zarządu województwa jako organów wykonawczych ${ }^{10}$. Organy stanowiace i kontrolne mają charakter przedstawicielski i kreowane są w drodze bezpośredniego wyboru przez mieszkańców - członków wspólnoty. Organy wykonawcze podlegają tej regule kreowania jedynie na poziomie organów gminy, natomiast skład personalny organu wykonawczego powiatu czy województwa wyłaniany jest tu pośrednio, tj. w drodze wyboru dokonywanego przez organ stanowiący i kontrolny powiatu, województwa. To kreowanie organów samorządu w drodze wyboru stanowi konsekwencję uznawania wspólnoty samorządowej za pierwszorzędny podmiot władzy w gminie, powiecie i województwie ${ }^{11}$, przy czym $\mathrm{w}$ odniesieniu do obsady organu stanowiącego i kontrolnego wybór z założenia (organ przedstawicielski) jest bezpośredni, natomiast w przypadku organu wykonawczego może znajdować zastosowanie także wybór pośredni, dokonywany zwykle przez organ stanowiący i kontrolny. Jak wiadomo, obowiązujące rozwiązania prawne dotyczace organów wykonawczych przewidują możliwość ich kreowania w drodze obu rodzajów wyborów ${ }^{12}$, z tym że wariantem niejako podstawowym jawi się tu wybór pośredni (dotyczący zarządów powiatów i zarządów województw) ${ }^{13}$, a zasada bezpośredniego wyboru wójtów gmin oraz burmistrzów i prezydentów miast rysuje się jako wyjątek od przyjętej (tradycyjnej zreszta) formuły ${ }^{14}$.

Obok sposobu kreowania istotnym elementem organizacyjnym modelu organów samorządu jest ich struktura, która może przybierać postać kolegialną bądź jednoosobową (monokratyczna). W dzisiejszych rozwiązaniach prawnych $\mathrm{w}$ tej materii dominują struktury kolegialne (wszystkie organy stanowiące i kontrolne oraz organy wykonawcze samorządu powiatowego i województwa (tudzież dzielnic m.st. Warszawy), a jedynie w przypadku organu wykonawczego samorządu gminnego mamy do czynienia $\mathrm{z}$ organem jednoosobowym (wójt, burmistrz, prezydent).

$\mathrm{Na}$ to zdecydowanie preferowane zastosowanie w przypadku organów jednostek samorządu terytorialnego struktury kolegialnej patrzeć można w kontekście szerszego, nie od dziś znanego i dyskutowanego, problemu wykorzystywania w organizacji aparatu administracji publicznej form kolegialnych

${ }_{10}$ Por. odpowiednio art. 11 ust. 1 , art. 15 ust. 1 , art. 26 ust. 1 u.s.g., art. 8 ust. 2 , art. 9 ust. 1 , art. 26 ust. 1 u.s.p., art. 15 , art. 16 ust. 1 oraz art. 31 ust. 1 u.s.w.

${ }^{11} \mathrm{~W}$ doktrynie traktowane jest to jako cecha konstytutywna samorządu terytorialnego, por. np. Dolnicki (2020): 14.

12 Co występuje także w regulacjach prawnych państw europejskich, o czym szerzej por. Dolnicki (2003): $289 \mathrm{n}$.

13 Także zarządów dzielnic w m.st. Warszawie.

14 Wprowadzona osobna ustawą z 20 czerwca 2002 r. o bezpośrednim wyborze wójta, burmistrza i prezydenta miasta, Dz. U. 2010, Nr 176, poz. 1191 ze zm. 
i jednoosobowych. Obie te formy organizacyjne prezentują określone zalety, ale i wady, co sprawia, że obie okazuja się przydatne w konstruowaniu struktur administracyjnych, problem zaś polega na takim dobraniu kolegialnej bądź monokratycznej formuły organu, która - ze względu na jej walory - najlepiej korespondowałaby z rola, funkcjami, zadaniami itd. tego organu. Tak np. kolegialność stwarza dla skupienia płaszczyznę w jednym organie reprezentantów różnych grup społecznych, zawodowych środowisk itp., przez co daje niejako naturalną możliwość wszechstronniejszego, wieloaspektowego rozpatrywania spraw i wyważania podejmowanych rozstrzygnięć. Stąd też organy kolegialne nadaja się $\mathrm{w}$ pierwszym rzędzie do funkcjonowania w tych obszarach spraw, które polegają na wytyczaniu kierunków działania, ustalaniu celów, określania zadań i priorytetów ich realizacji, podejmowania rozstrzygnięć o charakterze generalnym, wypowiadania się w sprawach ogólnych, złożonych, wymagających szerokiego ich wyświetlenia itd. Przy takich walorach kolegialności wskazuje się równocześnie, że jest to forma powolna w działaniu, „droższa” (w sensie ekonomicznym) niż forma jednoosobowa, trudniejsza przy ustalaniu odpowiedzialności za rozstrzygnięcia. Z kolei w odniesieniu do jednoosobowej struktury zwykle podnoszone są w szczególności takie zalety, jak szybkość działania, łatwa do sprecyzowania odpowiedzialność, relatywnie mniejsze koszty, natomiast wady to niebezpieczeństwo działań arbitralnych, mniejsze możliwości wyważania ocen i rozstrzygnięć, w efekcie większe prawdopodobieństwo powierzchowności w działaniu itp. Ze względu na walory jednoosobowej struktury uznaje się zazwyczaj, że lokowane powinny być w sferze działalności operatywnej, bieżącego administrowania, gdzie pierwszorzędne znaczenie ma sprawność i szybkość w realizacji przydzielonych funkcji i zadań.

Zestawienie kolegialności i jednoosobowości postrzegane z perspektywy zalet i wad tych form organizacyjnych ${ }^{15} \mathrm{i}$ w konsekwencji potencjalnych pól ich zastosowania w sferze administracji odzwierciedla jedynie w ogólnym, wręcz nieco schematycznym, ujęciu kwestię miejsca i znaczenia struktur kolegialnych i jednoosobowych w aparacie administracyjnym. Trzeba mieć na względzie, że walory i ułomności organów kolegialnych czy monokratycznych nie są bezwzględne i mogą być w jakimś stopniu korygowane za sprawą różnych rozwiązań prawnoorganizacyjnych. Ponadto warto zwrócić uwagę, że w problematyce obecności kolegialności i jednoosobowości w organizacji władzy publicznej pojawia się jeszcze inna istotna kwestia, a mianowicie wartościowanie tych form organizacyjnych przez pryzmat efektu politycznego (czy polityczno-ustrojowego), jaki towarzyszyć ma ich zastosowaniu.

Chodzi o to, że w szerokim przekonaniu społecznym, w praktyce, publicystyce, a także w jakimś stopniu także na płaszczyźnie dyskursu naukowego, kolegialność traktowana jest jako formuła, której zastosowanie wnosi niejako automatycznie pierwiastki demokratyczne do systemu organizacyjnego władzy publicznej (demokratyzację administracji) i nadaje mu bardziej „proobywatelski” wymiar. Przy tym podejściu jednoosobowość z kolei kojarzona jest

15 Generalnie relacje zalet i wad kolegialności oraz jednoosobowości układają się w ten sposób, że zalety jednej z tych form są odwrotnością wad drugiej z nich (a wady odwrotnością zalet). 
z władzą mniej demokratyczną, jednostronna, bardziej biurokratyczną niż działajaccą na rzecz obywateli.

Nie wchodząc w bliższe rozważania w materii wspomnianych wartości kolegialności (zwłaszcza) i jednoosobowości, należy, moim zdaniem, wyraźnie stwierdzić, że sygnalizowane stanowiska i oceny są zupełnie nieuprawnione, nie znajduja potwierdzenia ani z punktu widzenia regulacji prawnych, ani też doświadczeń praktycznych ${ }^{16}$. Kolegialność i jednoosobowość to po prostu dwie różne formy organizacyjne, które same w sobie są indyferentne pod względem ładunku politycznego i ustrojowego. I nie ma uzasadnienia przypisywanie tegoż ładunku zwłaszcza kolegialności, której zastosowanie miałoby automatycznie oznaczać demokratyzację systemu organizacyjnego władzy (administracji) publicznej. Oczywiście kolegialność, ale także i jednoosobowość moga stać się ważnym elementem demokratycznych struktur władzy (demokratyzacji oblicza tej władzy), ale jest to uzależnione od wielu czynników, takich jak np. przedstawicielski charakter organu, funkcje i zadania, jakie mu sa powierzane, miejsce w systemie, które ma zajmować, i szereg innych ${ }^{17}$.

Powracając na grunt tematyki organizacyjnej organów samorządu terytorialnego, w tym kwestii kolegialnej bądź monokratycznej ich struktury, należy uznać za rzecz oczywistą i bezdyskusyjną przyjęcie kolegialnej formuły w odniesieniu do organów stanowiących i kontrolnych. Sa to organy przedstawicielskie kreowane w drodze wyborów, reprezentujące różne grupy społeczne decydujące o sprawach ogólnych, podstawowych kierunkach z punktu widzenia rozwoju terenu oraz potrzeb i interesów mieszkańców. Naturalną koleja rzeczy zatem muszą one pozostawać w formule kolegialnej.

Inaczej natomiast wygląda sprawa w przypadku organów wykonawczych. Ich rola, funkcje i zadania, mieszczące się w sferze bieżącego, operatywnego zarządzania i administrowania, nie narzucaja przedstawicielskiej natury tychże organów, a nader ważną determinantą doboru ich struktury organizacyjnej jest zapewnienie sprawności, efektywności i odpowiedzialności w działaniu i realizacji zadań. Stąd w grę mogą tu wchodzić formy kolegialne i monokratyczne, co potwierdzają nie tylko rozwiązania polskie, ale także innych krajów europejskich ${ }^{18}$.

\footnotetext{
${ }^{16}$ Wystarczy przypomnieć doświadczenia Polski Ludowej z okresu lat pięćdziesiątych XX w., w którym to czasie w aparacie administracyjnym w terenie opartym na systemie rad narodowych, będących organami jednolitej władzy państwowej, dominowały struktury kolegialne, które nie zapewniały przecież demokratycznego mechanizmu sprawowania władzy. Można powiedzieć, że kolegialność była tu fasadą dla procesów rządzenia i administrowania zgoła niedemokratycznych.

17 Inaczej z perspektywy efektów polityczno-ustrojowych oceniać będziemy włączenie system organizacyjny administracji organów kolegialnych o charakterze przedstawicielskim i powierzenie im decydowania o sprawach o istotnym ciężarze gatunkowym i podstawowym znaczeniu, a inaczej organy przewidziane do decydowania w sprawach drobnych, o waskim profilu, technicznych czy też do wykonywania funkcji doradczych, opiniodawczych. Na podobnych zasadach można też oceniać efekty zastosowania organów monokratycznych.

${ }_{18}$ Według formuły monokratycznej zorganizowane są organy wykonawcze np. na poziomie powiatu w Niemczech, w departamentach i regionach we Francji czy prowincji w Hiszpanii. Przykładem kolegialnej formy organów wykonawczych mogą być z kolei okręgowy komitet wykonawczy w Szwecji czy zarząd regionu we Włoszech.
} 
Od początku reaktywowania samorządu terytorialnego w 1990 r. organy wykonawcze zorganizowane były i w większości są nadal w formule kolegialnej, kreowane personalnie w drodze wyborów pośrednich, z wyraźnie zaznaczonymi stanowiskami przewodniczących tych organów (zarządów). Od tej tradycyjnej, właściwej polskiemu prawu samorządowemu konstrukcji w 2002 r. dokonane zostało odstępstwo modelowe przez wprowadzenie na poziomie gminy organu monoktarycznego (wójt, burmistrz, prezydent), obsadzanego w drodze wyborów powszechnych, bezpośrednich i równych.

Przyjęte rozwiązanie, wynikłe w dużej mierze ze względów pragmatycznych dotyczących relacji: rada i jej przewodniczący a przewodniczący organu wykonawczego ${ }^{19}$, a po części z przesłanek sprawnościowych w zakresie funkcjonowania organu wykonawczego, od początku budziło dyskusje, a z upływem czasu (i obserwacji praktyki) stawało się też przedmiotem krytycznych ocen, dotyczących m.in. nadmiernego umocnienia wójta (burmistrza, prezydenta) i jego emancypacji w relacjach z rada, pogłębiającego jego konfliktu o władzę i prestiż z przewodniczącym rady, ograniczenia możliwości odwołania wójta w trakcie kadencji itd. ${ }^{20}$

Z perspektywy praktyki kilkunastu lat funkcjonowania obecnego modelu organu wykonawczego w gminie daje się oczywiście dostrzec różne niedostatki większej i mniejszej wagi w mechanizmie działania nie tylko samego tego organu, ale całego układu władz samorządowych na tym poziomie struktury samorządu. Wydaje się jednak, że nie są one prostym następstwem samej koncepcji organizacyjnej organu wykonawczego jako organu monokratycznego o obsadzie personalnej pochodzącej z bezpośredniego wyboru mieszkańców, ale mają swoje źródła w określonych regulacjach prawnych normujących różne konkretne szczegółowe aspekty normatywnego ukształtowania takiego modelu organu wykonawczego. Jeśli więc mówi się o problemach i praktycznych mankamentach związanych $\mathrm{z}$ istniejąca formuła organu wykonawczego, to należy mieć na uwadze, że jeśli nie ich wyeliminowanie, to przynajmniej istotne ograniczanie możliwe jest w drodze wypracowania lepszych rozwiązań prawnych dotyczących właśnie szeregu tych różnych konkretnych kwestii składających się na całościowy wymiar przyjętej konstrukcji ustrojowejeㄹ (jak np. w zakresie odwoływalności wójta, konsekwencji nieuzyskania przez niego absolutorium, wykonywania uchwał rady itd.).

19 Najogólniej biorąc, chodziło tu przede wszystkim o postępujące konkurowanie przewodniczącego rady z wójtem na płaszczyźnie działalności merytorytorycznej, ale także często ze względów prestiżowych, ambicjonalnych - por. Podemski (2015): 354.

${ }_{20}$ Por. tu np. bardzo krytyczną ocenę tego rozwiązania, a ściślej - jego praktycznych konsekwencji, dokonaną przez jednego z głównych autorów przywrócenia samorządu terytorialnego Jerzego Regulskiego (2005: 116-117), który pisał, że wzmacniając władzę wykonawcza, uczyniono z wójtów osoby wyposażone w pełnię władzy, ale wyłączone spod jakiejkolwiek kontroli, mogące całkowicie ignorować radę i jej uchwały i praktycznie nieodwoływalne.

${ }^{21}$ Rozwiązania prawne nie są stuprocentowym antidotum na bolączki praktyki, które maja swój zdecydowanie szerszy wachlarz przesłanek i wśród których jest też bardzo ważny tzw. czynnik ludzki, dotyczący kadr administracji. Niemniej przemyślane, stosowne rozwiązania prawne mogą w dużej mierze pozwolić na uniknięcie niepożądanych zjawisk w praktyce towarzyszących funkcjonowaniu istniejaccych konstrukcji organizacyjnych aparatu administracyjnego. 
Generalnie konstrukcja ta (model) wydaje się uzasadniona i sprawdza się $\mathrm{w}$ praktycznym funkcjonowaniu. W układzie władz samorządowych daje ono silny ośrodek wykonawczy, stwarzający możliwość sprawnego, operatywnego zarządzania i administrowania bieżącymi sprawami, który jest nieodzownym dopełnieniem ogniwa stanowiącego (uchwałodawczego) i kontrolnego wspomnianego układu.

IV. Kluczowym problemem dla zapewnienia harmonijnego i efektywnego mechanizmu działania władz samorządowych jest określenie (i prawne utrwalenie) relacji między organem stanowiącym i kontrolnym a organem wykonawczym. Nie analizując bliżej obowiązujących $w$ tej mierze relacji prawnych, chciałbym w tym miejscu jedynie zwrócić uwagę na pewną ogólną kwestię dotycząca ich postrzegania i oceniania. Chodzi mianowicie o to, że na relacje te, wzajemny układ obu tych organów patrzeć należy przez pryzmat ról i funkcji, jakie sa im przypisane w ramach całościowej koncepcji sprawowania władzy w jednostce samorządu terytorialnego. Te właśnie jasno zdefiniowane (przez m.in. w miarę możliwości precyzyjne ustalenie zakresów działania, zadań i kompetencji) role i funkcje obu kategorii organów stanowią zasadniczą determinantę stosunków między nimi, w tym możliwości oddziaływania, zależności (na płaszczyźnie przede wszystkim funkcjonalnej), współdziałania itp. Natomiast nie jest, moim zaniem, właściwe podejście zakładające, że z założenia rada jest organem ważniejszym, nadrzędnym funkcjonalnie i organizacyjnie wobec organu wykonawczego. Organ wykonawczy nie jest tu wszakże sytuowany na pozycji organu wykonawczo-zarządzającego rady (sejmiku) samorządowej22, lecz jest - tak jak i rada - orga ne m w s pólnoty samorządowej (gminy, powiatu, województwa), poprzez który członkowie tej wspólnoty (mieszkańcy) wykonują przekazany im obszar władzy (administracji) publicznej. W tym kontekście organy wykonawcze i organy stanowiące oraz kontrolne znajdują się na równorzędnej płaszczyźnie organizacyjnej w ramach ustalonego prawnie aparatu władzy każdej jednostki samorządu. Zróżnicowanie sytuacji tych organów i powstanie różnych między nimi relacji, w tym np. także o charakterze sui generis „zwierzchności” rady wobec organu wykonawczego, wypływa z prawem powierzonych im funkcji i zadań oraz przewidzianych środków (instrumentów) służących ich realizacji $^{23}$. Sprawa stosownych regulacji prawnych jest przyjęcie zatem takich rozwiązań, które przejrzyście odzwierciedlałyby rolę obu kategorii organów samorządu (przez ukonkretnienie ich funkcji i zadań oraz precyzyjniejszy ich

${ }^{22}$ Nie ma tu analogii do rozwiązań organizacyjnych w systemie rad narodowych, kiedy organ wykonawczy funkcjonujący obok przewidzianego organu władzy państwowej (rady narodowej) miał status właśnie organu wykonawczo-zarządzającego tegoż organu.

${ }^{23}$ Tak np. podjęcie przez radę (sejmik) w ramach realizowania jej funkcji stanowiącej określonej uchwały oznacza w układzie rada - organ wykonawczy, obowiązek tego drugiego z nich podjęcia działań mających na celu wykonanie tej uchwały. Podobnie z funkcji kontrolnej rady (sejmiku) wynika pewna, swoista „zwierzchność” rady wobec organu wykonawczego. 
podział) i tworzyły w przestrzeni relacji między nimi zabezpieczenia możliwości ich wypełniania ${ }^{24}$.

V. Powyższe uwagi dotyczące układu na linii organ stanowiaccy i kontrolny - organ wykonawczy mają odniesienie do relacji tych organów niezależnie od modelu organizacyjnego organu wykonawczego, aczkolwiek różne mankamenty i ułomności rozwiązań prawnych w tej materii podnoszone sa przede wszystkim na tle monokratycznej formuły organu wykonawczego na poziomie gminy.

Sprawa modelu organizacyjnego (struktury, ale i sposobu kreowania) organu wykonawczego to problem sam w sobie w obrębie zagadnień organizacji władz samorządowych, nad którym warto się chwilę zatrzymać. Jak wcześniej już wskazywałem, w moim przekonaniu, sprawdza się rozwiązanie przyjęte w przypadku wójta (burmistrza, prezydenta miasta). Powstaje pytanie ${ }^{25}$, czy nie warto byłoby rozważyć rozciagnięcia tej konstrukcji na pozostałe poziomy samorządu terytorialnego, a przynajmniej na poziom powiatowy. Powiat jako wspólnota samorządowa w świetle całościowej koncepcji ustrojowej samorzadu (realizowanej przez obowiązujący porządek prawny) jest ogniwem tego samorządu jednorodnym, gdy chodzi o cele, rolę, funkcje i zadania, z gminą. Oba te ogniwa w całej strukturze samorządu umiejscowione sa (i tak określane) jako samorząd lokalny, którego cele i zadania koncentrują się na zaspokajaniu potrzeb mieszkańców, dbałości o ich interesy, i załatwianiu ich spraw, a także na działaniach na rzecz rozwoju terenu.

Skoro mamy do czynienia z jednostkami samorządu o tożsamych relacjach i celach, to można zapytać, jakie przesłanki przemawiają za utrzymywaniem różnych rozwiązań organizacyjnych dotyczących tych jednostek. Czy też - już bardziej szczegółowo - jakie względy ważą na rzecz kolegialnego modelu organu wykonawczego powiatu?

Trudno na te pytania znaleźć przekonujace odpowiedzi. O ile jeszcze w odniesieniu do kolegialności organu wykonawczego województwa można podnosić, iż z racji przypisanej województwu samorządowemu roli i zadań ujętych generalnie jako dbałość o rozwój cywilizacyjny regionu, wytyczanie kierunków tego rozwoju, wybór priorytetów, a także pozyskiwanie i rozdzielanie środków finansowych, organ wykonawczy powinien mieć szeroki ogląd spraw i starannie wyważyć podejmowanie rozstrzygnięcia, czemu sprzyja struktura kolegialna, o tyle na poziomie powiatu, gdzie ma miejsce bieżace administrowanie i codzienne rozwiązywanie problemów i załatwianie spraw, pierwszorzędne znaczenie ma zapewnienie operatywnego aparatu wykonawczego, działającego sprawnie, rzetelnie i z jednoznacznie określoną odpowiedzialnościa, co łatwiejsze jest do osiagnięcia przy monokratycznej formule.

${ }^{24}$ Przykładowo, funkcja uchwałodawcza rady nie będzie miała realnego znaczenia, jeśli w układzie rada - organ wykonawczy organ wyposażony zostanie w możliwość odmowy wykonania uchwał rady.

25 Sygnalizowane w doktrynie - por. np. Dolnicki (2020): 14. 
Pójście w kierunku rozciagnięcia na poziom powiatu gminnego modelu organu wykonawczego byłoby uzasadnione i pożyteczne. Także z punktu widzenia pewnego porządkowania i „uczytelnienia” systemu organizacyjnego władz samorządowych.

VI. System ten formalnie klarowny, przy bliższym rozpatrzeniu okazuje się dość złożony. Chodzi tu w pierwszej kolejności o szczególne usytuowanie przewodniczących kolegialnych organów wykonawczych (zarządów) w powiecie i województwie. Już tylko przepisy ustrojowe (u.s.p., u.s.w.) kształtują silna pozycję starosty i marszałka województwa, wykraczająca znacznie poza stanowisko przewodniczącego organu kolegialnego, który organizuje pracę tego organu i reprezentuje go na zewnątrz. W świetle szeregu unormowań ustawowych można stwierdzić, że pozycja starosty, jak i marszałka województwa wyraźnie steruje w kierunku ich statusu jako osobnych samodzielnych organów administracji. Tak np. starosta (marszałek) kierują bieżącymi sprawami powiatu/ województwa, organizują pracę podległych im urzędów, reprezentują jednostki sa morządu (a nie tylko zarządy, którym przewodnicza) na zewnątrz, są organami wydajacymi - co do zasady - decyzje administracyjne - w sprawach indywidualnych z zakresu administracji publicznej należące do właściwości powiatu/ województwa ${ }^{26}$. W przypadku starosty wyeksponowana jest też jego funkcja zwierzchnika powiatowej administracji zespolonej27, której ujęcie w przepisach potwierdza, że mamy tu do czynienia z osobnym organem administracyjnym. Taki status zarówno starosty, jak i marszałka województwa dopełniaja inne, np. prawnomaterialne, regulacje porządku prawnego, przypisujace im zadania i kompetencje adresowane bezpośrednio do nich (a nie do zarządów którym przewodniczą i które następnie w imieniu tychże zarządów wykonuja). Skoro mamy do czynienia z podmiotami o charakterze samoistnych organów to pojawia się pytanie, jakiego rodzaju (czyje) sa to organy w systemie władz samorządowych. Według u.s.p. i u.s.w. nie są to organy powiatu czy samorządu województwa. Nie są to oczywiście też jakieś swego rodzaju organy kolegialnych organów wykonawczych. Sprawa doprecyzowania pomieszczenia tych organów w systemie organizacyjnym powiatu czy województwa stanowi ważną kwestię z punktu widzenia klarowności i spójności całej kompozycji władz samorządowych. Sygnalizowany problem zniknąłby przy rozciagnnięciu na poziom powiatu i województwa gminnego modelu organu wykonawczego. Do rozważenia mogłoby być także włączenie starosty i marszałka do rozszerzonego katalogu organów powiatu czy województwa.

VII. Dokonany w dotychczasowych uwagach przegląd zagadnień ze sfery organizacji władz samorządowych nie jest oczywiście wyczerpujacy. Gdyby kontynuować tę tematykę, to można byłoby podnieść szereg innych jeszcze spraw dotyczacych rozwiązań prawnoorganizacyjnych w tym zakresie, czasami kontrowersyjnych i dyskusyjnych. Przykładem może być tu wyposażenie

${ }_{26}$ Por. odpowiednio zwłaszcza art. 34 i art. 38 u.s.p., art. 43 i art. 46 u.s.w.

27 Por. art. 33, 33a, 33b u.s.p. oraz Gajewski, Jakubowski (2018). 
przewodniczących organów stanowiących gmin, powiatów i województw w prawo wydawania poleceń służbowych pracownikom samorządowym w urzędach tych jednostek, którzy w ramach swoich stanowisk pracy wykonuja zadania organizacyjne, prawne i inne związane $\mathrm{z}$ funkcjonowaniem tych organów, ich komisji oraz radnych, a także przyznanie przewodniczącym funkcji zwierzchnika służbowego wobec tych pracowników samorządowych ${ }^{28}$. Inne przykłady to m.in. sprawa rozbudowywania w obrębie organu stanowiącego, a także przy organie wykonawczym powiatu ciał kolegialnych o niekiedy niejasnym położeniu prawnym, roli i celach (rady młodzieży, rady seniorów, komisja skarg, wniosków i petycji, czy komisja bezpieczeństwa i porządku) czy też kwestia wprowadzenia na poziomie województwa instytucji klubu opozycyjnego wobec zarządu (art. 23 ust. 3a u.s.w.). Ramy artykułu nie dają możliwości rozwinięcia wspomnianych przykładowo kwestii czy podjęcia kolejnych wątków interesujacej tematyki.

Pozostajac więc przy do tej pory przedstawionych uwagach, można w tym miejscu co najwyżej zamknać zawarte w nich rozważania pewnym ogólnym podsumowaniem.

VIII. Otóż trzydzieści lat doświadczeń reaktywowanego samorządu terytorialnego pokazuje, że dla jego pozycji i roli jako trwałego komponentu ustroju społeczno-politycznego, prawnego i gospodarczego, obok skali przydzielonej władzy publicznej (zadań i kompetencji), posiadania odpowiednich podstaw materialnych i finansowych, bardzo ważne znaczenie ma jego strona organizacyjna, w tym w szczególności organizacja (i zasady funkcjonowania) władz wspólnot samorządowych. Kształtują ją określone rozwiązania prawne, które nie tylko muszą być adekwatne do aktualnych uwarunkowań w postaci stosunków społecznych, gospodarczych, kulturowych i wynikających z nich potrzeb i zadań, ale także tworzyć sprawny mechanizm nadążający za procesem zmian w tym zakresie. To oznacza, że ten organizacyjny system samorządu, a zwłaszcza jego władz, winien być systematycznie monitorowany i konsekwentnie ulepszany.

Obowiązujące prawnoorganizacyjne rozwiązania w zakresie władz samorządowych nadaja im kształt, który w generalnym wymiarze nie budzi zastrzeżeń ani nie wymaga jakiejś istotnej przebudowy. Patrząc jednak bardziej szczegółowo na całościowy obraz unormowań dotyczących konstrukcji tych władz, można dostrzec określone obszary, co do których rysują się potrzeby dokonania pewnych korekt, a przynajmniej ich rozważania.

Jeden z nich to ujęcie segmentu władz, jaki stanowią mieszkańcy (członkowie wspólnoty). Dzisiejsze ujęcie jest ogólne, brakuje w nim stwierdzenia, że władza w takiej czy innej jednostce samorządu należy do członków wspólnoty (taka deklaracja wyrażana jest dziśs w okrężny sposób). Warto chyba rozwinaćc ustawową koncepcję władzy w samorządzie, akcentując silniej i precyzyjniej rolę mieszkańców jako podmiotu tej władzy.

28 Por. art. 21 u.s.g., art. 19 u.s.p., art. 21a u.s.w. Rozwiązanie to jest mocno krytykowane w doktrynie - por. np. Korczak (2020): 97 n. 
Towarzyszyć temu powinno też wskazanie instrumentów sprawowania władzy przez członków wspólnoty w katalogu nieograniczającym się do wyborów organów i referendum. Ponadto potrzebne wydaje się rozwinięcie konstrukcji tych instrumentów w kierunku ich „urealnienia” jako skutecznych środków (sposobów) wykonywania władzy (dotyczy to zwłaszcza referendum, które w obecnym ujęciu prawnym, organizacyjnym i technicznym, niejednokrotnie okazuje się w praktyce instrumentem o niewielkiej efektywności).

Inny obszar wymagajacy „korektur ulepszających” stanowią unormowania dotyczace relacji organ stanowiący i kontrolny - organ wykonawczy. W „ulepszeniach" tych idzie o działania na rzecz jednoznacznego, klarowniejszego układu tych organów, który odwołując się do różnych ich ról i funkcji, nie będzie stwarzał pola do konkurowania ich ze sobą (i generowania konfliktów), ale sterował ku relacjom opartym na współpracy, uzupełnianiu się i wspomaganiu. Drogą do uzyskania takiego efektu jest uzupełnianie i precyzowanie rozwiązań prawnych odnoszących się do pozycji obu kategorii organów, ich zadań, kompetencji, a także możliwości wzajemnego oddziaływania na siebie (np. w odniesieniu do problemu domniemania kompetencji w poszczególnych ogniwach samorządu na poziomie gminy istnieje ono na rzecz rady, regulacje powiatowe w ogóle zajmuja stanowiska w tej mierze, w województwie zaś domniemanie to ustanowione jest na rzecz zarządu województwa).

Niekiedy niezbędne może tu być też wycofanie się z przyjętych rozwiązań, jak np. w przypadku ,wzmocnienia” pozycji przewodniczących rad samorządowych i sejmiku o funkcje zwierzchnika służbowego wobec niektórych pracowników urzędu gminy, starostwa czy urzędu marszałkowskiego.

Ważnym fragmentem regulacji, powiązanym z unormowaniami odnoszącymi się do kwestii organizacji władz samorządowych, jawią się regulacje mające za przedmiot kreowanie rozwiązań i instytucji służących partycypacji społeczności wspólnot w rozwiązywaniu spraw lokalnych i w jakimś zakresie w sprawowaniu funkcji władzy. Aczkolwiek dziś nie jest to puste pole, to jednak jego zagospodarowanie pozostaje sprawą otwarta. Z jednej strony chodzi o wspominane już ulepszenie (rozwijanie, doprecyzowanie, modyfikowanie itd.) istniejaccych instytucji prawnych (np. budżet obywatelski, inicjatywa uchwałodawcza, udział w dyskutowaniu raportu o stanie jednostki samorządu terytorialnego, rada seniorów, rada młodzieży), z drugiej - o podejmowanie nowych rozwiązań, adekwatnych do społecznych aspiracji uczestniczenia w sprawach publicznych (niekiedy wcale nie oczywistych), które będą zapewniać realny wpływ różnych grup społecznych na te sprawy. Przy tych nowych inicjatywach trzeba baczyć na ich rzetelność, gdy chodzi o cele, którym mają służyć. Jest to przestroga przed uleganiem pokusom sięgania do rozwiązań (zwłaszcza instytucjonalnych), które - tak jak np. szerokie stosowanie kolegialnych struktur organizacyjnych - tylko w takim potocznym pojmowaniu gwarantują otwarcie drzwi dla społecznej partycypacji w zarządzaniu, w istocie zaś stanowią tylko atrapy takiego otwarcia ${ }^{29}$.

${ }^{29}$ Wystarczy przeanalizować prawne opisanie pozycji np. rady seniorów czy rady młodzieży i wynikające stąd znaczenie tych podmiotów w podniesionej tu kwestii. 
I wreszcie bodajże najważniejsza płaszczyzna, na której może (powinno?) dojść do zmian o charakterze rekonstrukcji. Chodzi tu o problem zastosowania modelu organu wykonawczego istniejaccego $\mathrm{w}$ gminie na poziomie powiatu i województwa. Moim zdaniem sprawa jest warta rozpoczęcia dyskusji.

Wszystkie sygnalizowane korekty mają wspólny mianownik co do celu, jaki im przyświeca. Chodzi o stworzenie wyrazistego, spójnego mechanizmu władzy samorządowej, który spełniając ideowe założenia samorządzenia się społeczności lokalnych, tworzyłby silny i sprawny ośrodek dyspozycyjno-wykonawczy w powierzonym przez państwo zakresie spraw publicznych. Co może być ważkim argumentem wobec tych tendencji, które podważają rolę i znaczenie samorządu terytorialnego w systemie ustrojowym państwa i administracji publicznej.

Jacek Jagielski

Uniwersytet Warszawski

j.jagielski@wpia.uw.edu.pl

https://orcid.org/0000-0002-3033-3282

Dolnicki, B. (2003). Samorząd terytorialny. Kraków.

Dolnicki, B. (2020). Sprawność działania administracji samorządowej. Samorząd Terytorialny 3(351): 9-25.

Dubisz, S. (red.) (2006). Uniwersalny słownik języka polskiego. Warszawa.

Gajewski, S., Jakubowski, A. (red.) (2018). Ustawy samorządowe. Komentarz. Warszawa.

Korczak, J. (2020). Nowe uprawnienia przewodniczących organów stanowiących jednostek samorządu terytorialnego. Refleksje doktrynalne nad praktyką i orzecznictwem. Samorząd Terytorialny 3(351): 97-120.

Podemski, K. (2015). Deficyt obywatelstwa. Ruch Prawniczy, Ekonomiczny i Socjologiczny 77(3): $351-368$.

Regulski, J. (2005). Samorządna Polska. Warszawa.

Zimmerman, J. (2015). Jurysdykcyjna ranga samorządowych kolegiów odwoławczych. Ruch Prawniczy, Ekonomiczny i Socjologiczny 77(1): 131-146.

\section{ON THE LEGAL AND ORGANIZATIONAL ISSUES OF LOCAL SELF-GOVERNMENT AUTHORITIES (SOME COMMENTS AND REFLECTIONS ON SELECTED ISSUES)}

$$
\text { Sum mary }
$$

The article deals with several issues in the field of legal and organizational issues related to local self-government authorities. Starting from the definition of the category of authorities, the author applies it to local self-government, identifying the legal basis of local self-government authorities. Then selected problems of legal and organizational solutions concerning individual authorities are presented, with an emphasis on the basic subjects of local self-government, namely the community members (residents) of communes (gmina), poviats and voivodships. The considerations focus on such issues as: the ways of exercising power by members of the community directly, the use of collegiality and one-person character in the organization of authorities, building agreements and relations between self-government bodies, and the issue of shaping legal institutions serving social participation in the sphere of public affairs. The conclusions of the deliberations address the need to modernize legal solutions in the field of local self-government authorities.

Keywords: local self-government; authority; local authority; local self-government bodies; administrative bodies; model of executive bodies; modernization of the legal solutions 